\title{
Assessment of Heavy Metal Accumulation in Wastewater Irrigated Soil and Uptake by Maize Plants (Zea Mays L) at Firle Farm in Harare
}

\author{
Chipo Masona (Corresponding author) \\ Department of Environmental Science, Bindura University of Science Education \\ P. Bag 1020, Bindura, Zimbabwe \\ Tel: 263-772-974-780Ｅ-mail: chipomasona@yahoo.co.uk \\ Loveness Mapfaire, \\ Department of Environmental Science, Bindura University of Science Education \\ P. Bag 1020, Bindura, Zimbabwe \\ Tel: 263-772-953-353Ｅ-mail: lovemapfaire@gmail.com \\ Stenly Mapurazi \\ Department of Environmental Science, Bindura University of Science Education \\ P. Bag 1020, Bindura, Zimbabwe \\ Tel: 263-773-393-082Ｅ-mail: smapurazi@buse.ac.zw
}

Revai Makanda

University of Zimbabwe Soil Science Agricultural Engineering

P O Box 167 Mt Pleasant, Harare, Zimbabwe

E-mail: revie@afritechno.com

Received: August 26, 2011

doi:10.5539/jsd.v4n6p132
Accepted: October 8, $2011 \quad$ Published: December 1, 2011

URL: http://dx.doi.org/10.5539/jsd.v4n6p132

\begin{abstract}
A study was carried out in March 2010 at Firle Sewage Works in Harare, Zimbabwe to determine the effects of long term wastewater irrigation on the concentrations of heavy metals $(\mathrm{Zn}, \mathrm{Cu}, \mathrm{Mn}, \mathrm{Cd}, \mathrm{Pb}, \mathrm{Ni}, \mathrm{Fe}$ and $\mathrm{Cr}$ ) in soil, and their subsequent accumulation in maize plants. The study revealed that long term wastewater use for irrigation results in heavy metal accumulation in soils and bioaccumulation in plants beyond maximum permissible limits (MPL) for both humans and livestock consumption. Lead had highest transfer factor and iron had the least transfer factor. The soil $\mathrm{pH}$ was found to be less acidic $(\mathrm{pH}=5.6)$ in soils exposed to waste water than in soils where no wastewater had been applied $(\mathrm{pH}=5)$. As a recommendation there is need for phytoextraction of heavy metals by intercropping maize plants with local agro forestry shrubs to reduce amount of heavy metals in the soil.
\end{abstract}

Keywords: Heavy metals, Wastewater, Maize, Maximum permissible limits

\section{Introduction}

Wastewater disposal is becoming a problem in developing countries as large quantities of municipal waste and industrial effluent are being produced due to increased urbanization and industrialization respectively (Alloway \& Ayres, 1995). The major challenge is how to deal with the waste which is being released at a rate faster than its proper disposal. In many countries of the third world, one of the options for dealing with wastewater is to use it in agricultural land as a way of disposing it (Oloya \& Tagwira, 1996). Repeated irrigation of crops with wastewater however, can have significant effects on the physical and chemical properties of soil. The continued 
use of wastewater for irrigation may result in the accumulation of heavy metals sometimes to levels above the permissible limits for both animal and human health as specified by World Health Organization (WHO) standards. In municipal solid waste stream, which is another possible source of wastewater, heavy metals emanate from a variety of sources. The major ones are batteries, consumer electronics, ceramics, light bulbs, house - dust and paint chips, lead foils such as wine bottle closures, used motor oils, plastics, and some inks and glass (Woodbury, 1993). This is a typical example of how the increase in anthropogenic activities has led to the emission of various pollutants into the environment and how different types of hazardous substances are introduced in the soil and land environments (Kho et al., 2007).

In Zimbabwe, wastewater application is limited to municipal farms and peri-urban farms. Firle Sewage Treatment Works is one of the biggest sewage treatment plants that processes both domestic and industrial effluent and is situated at Firle Farm, south west of Harare city. The wastewater treatment plant consists of six units with a capacity to process $108 \mathrm{~m}^{3}$ of effluent per day (Madyiwa et al., 2002). Firle farm is thus, an example of areas where wastewater has been used for irrigating various crops such as maize for more than 30 years. The practice has many benefits which include low cost disposal method for wastewater, and improved use and conservation of water in arid and semi-arid conditions (Mapanda et al., 2005). Using wastewater for irrigating crops provides nutrients such as phosphorus and nitrogen that are necessary for cropping purposes (Nyamangara \& Mzezewa, 1999).

According to Dougherty and Hall (1995), the long term use of wastewater in agricultural land is resulting in the contamination of soils by heavy metals. These heavy metals include zinc $(\mathrm{Zn})$, cadmium $(\mathrm{Cd})$, copper $(\mathrm{Cu})$, and nickel $(\mathrm{Ni})$, lead $(\mathrm{Pb})$, manganese $(\mathrm{Mn})$, iron $(\mathrm{Fe})$, mercury $(\mathrm{Hg})$ and chromium $(\mathrm{Cr})$. Though most heavy metals are needed in trace amounts by growing plants, their excess can result in plant intoxication. The occurrence of heavy metals in industrial wastewater is of interest because they are often present at significant levels and if discharged into surface waters can have severe effects on the environment and public health. Thus the presence of high heavy metal concentrations in plant tissues brings about poisoning problems in human beings and other animals feeding on specific plant tissues (Alloway \& Ayres, 1995). Therefore, in order for wastewater irrigation to be sustainable there is need for careful and planned management to ameliorate the negative impacts that may arise.

The studies carried out in Zimbabwe on heavy metals concentrations in maize concentrated mainly on the following heavy metals: $\mathrm{Zn}, \mathrm{Cu}, \mathrm{Cd}$, and $\mathrm{Pb}$ which are considered to be the regulated elements (Muchaweti et al., 2006). The concentrations of heavy metals in plants also depend on application rate, soil reactions and plant species (Zoubi, 2008). This is partially evidenced by a study in India in 2008 that indicated that Cr increased significantly in roots as the sludge application increased. As such, there is always need to undertake studies for investigating heavy metal accumulation in areas exposed to waste water. It is against this background that this study was carried out to determine the effects of long term wastewater irrigation on the accumulation of $\mathrm{Zn}, \mathrm{Cu}$, $\mathrm{Pb}$ and $\mathrm{Cr}, \mathrm{Mn}, \mathrm{Cd}, \mathrm{Ni}$, and $\mathrm{Fe}$ in soil and in maize plants, so as to establish a basis for environmental protection and reduce negative implications on human and livestock health.

\section{Materials and methods}

The study was conducted at Firle farm located on the outskirts of Glenview in Harare, Zimbabwe. Harare is in the sub tropical region of Africa with cold, dry winters and hot, wet summers. Average annual rainfall is about $850 \mathrm{~mm}$ and average annual temperature is $18-20{ }^{\circ} \mathrm{C}$. Firle farm is located adjacent to Firle Sewage Treatment Works (FSTW) and lies between $17^{\circ} 55^{\prime} 37^{\prime \prime} \mathrm{S}$ and $17^{\circ} 53^{\prime} 55^{\prime \prime} \mathrm{S}$, and between $30^{\circ} 57^{\prime} 19^{\prime \prime} \mathrm{E}$ and $30^{\circ} 57^{\prime} 22^{\prime \prime} \mathrm{E}$. Maize plants were grown on two sites; SITE A which is on Firle farm and had been wastewater irrigated for more than 30 years, and SITE B which was the control site and had not been exposed to sewage irrigation before. The two sites have sandy soils and are both located on the same gently, undulating terrain of about $2-3 \%$ slope. The maize plants on both site A and site B were irrigated using equal rates of clear water. Three soil samples were collected from each site at depth $0-20 \mathrm{~cm}$ for heavy metal analysis. Subsequently, the samples were air dried under shed to halt biological transformations, and then sieved through a $2 \mathrm{~mm}$ sieve and stored at $4^{\circ} \mathrm{C}$. Heavy metal $(\mathrm{Zn}, \mathrm{Cu}$, $\mathrm{Ni}, \mathrm{Cd}, \mathrm{Pb}, \mathrm{Mn}, \mathrm{Cr}$ and $\mathrm{Fe}$ ) concentrations of the soil samples were then determined using Atomic Absorption Spectrophotometry (AAS). The $\mathrm{pH}$ for the soil samples was determined using a $220 \mathrm{pH}$ meter which had been calibrated using $\mathrm{pH} 4$ and $\mathrm{pH} 7$ solution.

Plant sampling from both site A and site B was done at harvest stage. Heavy metal concentrations in maize cobs were analyzed separate from the rest of the plants, and in both cases AAS was used. Statistical analysis of the results was done using SPSS version 16 of 2004. One way Analysis Of Variance (ANOVA) was used to test for statistical differences in heavy metal accumulations between the two sites, and between their respective plants at 
0.05 significance level. The impact of heavy metal contamination and the resulting health risk was revealed through the transfer factor (TF) from soil to crop (Cui et al., 2004). The transfer factor characterizes the transfer of a heavy metal from the soil to the plant.

\section{Results}

The study showed that long-term wastewater irrigation on agricultural lands significantly increases the concentration of heavy metals in soils, and has an effect on the subsequent accumulation in maize plants. Tables (1-4) are presented which show concentrations of the heavy metals in soils, plant and cob, for both site A and site B. For all the selected heavy metals, mean concentrations were significantly higher $(\mathrm{p}<0.05)$ on site A, previously exposed to wastewater for more than 30 years than on site $\mathrm{B}$ that had never been exposed to wastewater before. Concentrations of $\mathrm{Cu}, \mathrm{Zn}, \mathrm{Cd}, \mathrm{Ni}$ and $\mathrm{Cr}$ in wastewater irrigated soils were above the United States Environmental Protection Agency (USEPA) Maximum Permissible Limits. The soil $\mathrm{pH}$ was found to be less acidic $(\mathrm{pH}=5.6)$ in soils exposed to wastewater than in the area where no wastewater had been applied before $(\mathrm{pH}=5)$, (Table 1).

The mean concentrations of $\mathrm{Cu}, \mathrm{Zn}, \mathrm{Mn}, \mathrm{Pb}$ and $\mathrm{Fe}$ in maize plants from site A were significantly higher $(\mathrm{p}<$ 0.05 ) than in maize plants sampled from site $\mathrm{B}$, (Table 2). The mean concentrations of $\mathrm{Cd}, \mathrm{Ni}, \mathrm{Pb}$ and $\mathrm{Zn}$ in maize plants harvested from soils exposed to wastewater were found to be above the WHO maximum permissible limits for adult livestock feeding (Table 2). On the other hand $\mathrm{Cr}, \mathrm{Fe}, \mathrm{Cu}$ and $\mathrm{Mn}$ were within the acceptable limits.

For all the selected heavy metals the mean concentrations in maize cobs from site A were significantly higher (p $<0.05$ ) than from site $\mathrm{B}$. On site $\mathrm{A}$ the mean concentrations of $\mathrm{Zn}, \mathrm{Pb}, \mathrm{Cd}, \mathrm{Ni}$ and $\mathrm{Cr}$ in maize cobs were above WHO maximum permissible limits, while the mean concentrations for $\mathrm{Cu}, \mathrm{Mn}$ and $\mathrm{Fe}$ in cobs from site A were within the WHO maximum permissible limits (Table 3).

The transfer factors between soil and plant for those heavy metals whose concentrations in maize plant (without cobs) were significantly higher on site A than on site B were in the order: $\mathrm{Pb}>\mathrm{Zn}>\mathrm{Mn}>\mathrm{Cu}>\mathrm{Fe}$ (Table 4).

\section{Discussion}

The study revealed that wastewater increases heavy metal concentrations in soils (Tables 1). This agrees with Schmidt (1997) that toxic heavy metals, in particular $\mathrm{Cd}, \mathrm{Cu}, \mathrm{Zn}, \mathrm{Ni}$ and $\mathrm{Pb}$ are frequently present in high concentrations in wastewater. These heavy metals are then transferred from the soil to the plant including the cob (Table 4 and Table 5), and are potential health problems to humans and animals feeding upon them. Concentrations of $\mathrm{Cd}, \mathrm{Cu}, \mathrm{Zn}, \mathrm{Ni}$ and $\mathrm{Cr}$ in wastewater irrigated soils were found to be above the United States Environmental Protection Agency (USEPA) maximum permissible limits. Due to bioaccumulation, the heavy metal concentrations in wastewater irrigated soils were transferred to plants, and the study revealed that $\mathrm{Pb}$ has the highest transfer factor (0.59) whilst Fe has the least (0.025). Livestock which feed from maize plants grown on soils exposed to wastewater are at a high risk of $\mathrm{Cd}, \mathrm{Ni}, \mathrm{Pb}$ and $\mathrm{Zn}$ poisoning since their levels were found to be above the maximum permissible limits in plants for livestock feeding. The long term application of wastewater on soils to irrigate crops can also increase human exposure to heavy metals, and of much concern are $\mathrm{Cd}, \mathrm{Cr}, \mathrm{Ni}, \mathrm{Pb}$ and $\mathrm{Zn}$, whose levels in the samples of maize cobs were higher than the maximum permissible limits. Previous studies done by Mapanda et al. (2005) on vegetables revealed increasing concentrations of heavy metals (copper, zinc, cadmium, nickel, chromium and lead) in soils irrigated with wastewater for ten years. There is therefore need for alerting residents about toxic effects of metals since some of these metals such as $\mathrm{Pb}$, $\mathrm{Cd}$ and $\mathrm{Cr}$ are considered hazardous contaminants that can accumulate in the human body, with a relatively long half-life. Children will be at more risk due to their relatively lower body masses. Ingesting very high levels of Cd severely irritates the stomach, leading to vomiting and diarrhea. Long-term exposure to lower levels leads to a buildup in the kidneys and possible kidney disease, lung damage, and fragile bones (McLaughlin et al., 1999). A higher soil $\mathrm{pH}$ found on site A (wastewater exposed soil) as compared to site $\mathrm{B}$ (Table 1) reflects that wastewater has a positive effect on agricultural soils as it reduces acidity. However, the soil pH on site A is still lower (more acidic) than the common recommendation desired for soils exposed to wastewater, that it should be above 6-6.5 (Sommers et al., 1987).

\section{Conclusion}

The long term use of wastewater in irrigation resulted in increased heavy metal concentrations namely $\mathrm{Cu}, \mathrm{Zn}$, $\mathrm{Mn}, \mathrm{Pb}, \mathrm{Cd}, \mathrm{Ni}, \mathrm{Fe}$ and $\mathrm{Cr}$ in soil. These metals are then transferred to plants before being transferred to the human body and livestock. This is a potential health risk to the urban farmers who make use of many vacant lands which have been exposed to wastewater for growing maize crops and vegetables. There is therefore need 
for satisfactory soil quality monitoring procedures so as to prevent potential health hazards of wastewater application on agricultural land. Even though a number of methods dealing with heavy metal removal have been investigated such as those involving addition of substances that bind metals to form sparingly soluble compounds which are not leached by rain, future studies in Zimbabwe should consider biological removal of heavy metals by intercropping maize plants with local agro forestry tree/shrub species in soils irrigated with wastewater. The concentration of heavy metals in plants is a function of the application rate, soil reactions (including soil type) and plant species therefore future studies should also aim at determining the appropriate wastewater application rates on various types of crops.

\section{References}

Alloway, B. J. (1995). Heavy Metals in Soils. Blackie Academic Press, New York.

Arora, M., K. Bala, S. Rani, A. Rani, B. Kaur \& N. Mittal. (2008). Heavy metal accumulation in vegetables irrigated with different water sources. Food Chemistry. 111, 811-815. http://dx.doi.org/10.1016/j.foodchem.2008.04.049

Cui, Y. J., Zhu, Y. G., Zhai, R. H., Chen, D. Y., Huang, Y. Z. \& Qui. (2004). Transfer of metals from soil to vegetables in an area near a smelter in Nanning China. Environment International. 30, 785-91. http://dx.doi.org/10.1016/j.envint.2004.01.003

Dougherty, T. C. \& Hall, A. W. (1995). Environmental impact assessment of irrigation and drainage projects. FAO Irrigation and Drainage Paper 53. ISBN 92-5-103731-0. [Online] Available: http://www.fao.org/docrep/v8350e/v8350e00.htm

Kho, F. W. L., Law, P. L., Ibrahim, S. H. \& Sentian, J. (2007). Carbon monoxide levels along roadway. International Journal Environment Science and Technology. 4 (1), 27-34.

Madyiwa, S., Chimbari, M., Nyamangara, J. \& Bangira, C. (2002). Cumulative effects of sewage sludge and effluent: Mixture application on soil properties of a sandy soil under a mixture of star and kikuyu grasses in Zimbabwe. Physic Chemistry of the Earth. 27, 747-753. http://dx.doi.org/10.1016/S1474-7065(02)00062-1

Mapanda F., Mangwayana E. N., Nyamangara J. \& Giller K. E. (2005). the effects of long-term irrigation using wastewater on heavy metal contents of the soil under vegetables in Harare, Zimbabwe. Agriculture, Ecosystems and Environment. 107 (2-3), 151 - 165. http://dx.doi.org/10.1016/j.agee.2004.11.05

Muchuweti, M., Birkett, J. W., Chinyanga, E., Zvauya, R., Scrimshaw, M. D. \& Lester, J. N. (2006). Heavy metal content of vegetables irrigated with mixture of wastewater and sewage sludge in Zimbabwe: implications for human health. Agriculture, Ecosystem and Environment. 112, 41-48. http://dx.doi.org/10.1016/j.agee.2005.04.028

Nyamangara, J. \& Mzezewa, J. (1999). The effect of long - term sewage sludge application on $\mathrm{Zn}, \mathrm{Cu}$, Ni, and $\mathrm{Pb}$ levels in a tropical soil under pasture grass. Agriculture, Ecosystems and Environmental. 73, 199-204. http://dx.doi.org/10.1016/S0167-8809(99)00056-0

Oloya, T. \& Tagwira, F. (1996). Land disposal of sewage sludge and effluent in Zimbabwe. Effect of applying sewage sludge and effluent on elemental accumulation and distribution in soil profile. Zimbabwe Journal of Agriculture Research. 34, 11-18.

Schmidt, J. P. (1997). Understanding phytotoxicity threshold for trace elements in land-applied sewage sludge. Journal of Environment Quality. 26, 4-10. http://dx.doi.org/10.2134/jeq1997.00472425002600010002x

Sommers L. E., Van Volk, V. Giordano P. M., Sopper, W. E. \& Bastian, R. (1987). Effects of soil properties on accumulation of trace elements by crops. In: AL Page, TJ Logan and JA Ryan (eds.) Land Application of Sludge. Food Chain Implications. Lewis, Chelsea.

USEPA (US Environmental Protection Agency). (1997). Exposure Factors Handbook. Volume II-Food Ingestion Factors. EPA/600//P-95/002Fa.Office of Research and Development. Washington, DC, USA.

WHO. (1996). Trace elements in human nutrition and health. World Health Organisation. Geneva.

Woodbury, P. B. (1993). Potential effects of heavy metals in municipal solid waste compost on plants and the environment, Boyce Thompson Institute for Plant Research at Cornell University Rice Hall • Ithaca, NY 14853 • (607) 255-1187.

Zoubi, M. M. Al, Arslan, A. Abdelgawad, G. Pejon, N. Tabbaa, M. \& Jouzdan, O. (2008). The Effect of Sewage Sludge on Productivity of a Crop Rotation of Wheat, Maize and Vetch) and Heavy Metals Accumulation in Soil 
and Plant in Aleppo Governorate. American-Eurasian Journal of Agricultural \& Environmental Sciences. 3 (4), 618-625.

Table 1. $\mathrm{pH}$ and Mean heavy metal concentrations $(\mathrm{ppm} \pm \mathrm{SE}$ ) in soil exposed to waste water irrigation before (site A) and in soil that had never been exposed to waste water irrigation before (site B)

\begin{tabular}{|c|c|c|c|c|c|c|c|c|c|}
\hline & \multicolumn{7}{|c|}{ Heavy metal concentrations (ppm \pm SE) } & \\
\hline Treatment & $\mathrm{Cu}$ & $\mathrm{Zn}$ & $\mathrm{Mn}$ & $\mathrm{Pb}$ & $\mathrm{Cd}$ & $\mathrm{Ni}$ & $\mathrm{Fe}$ & $\mathrm{Cr}$ & $\mathrm{pH}$ \\
\hline Site A & $94.4 \pm 1.9$ & $285.37 \pm 2.3$ & $77.5 \pm 1.44$ & $94 \pm 1.15$ & $4.8 \pm 0.4$ & $55.6 \pm 1.7$ & $31808 \pm 993$ & $936.5 \pm 2.02$ & 5.6 \\
\hline Site B & $8.5 \pm 0.29$ & $32.5 \pm 1.44$ & $61.5 \pm 0.86$ & $16.7 \pm 0.9$ & $1.5 \pm 0.3$ & $6.6 \pm 0.8$ & $21247 \pm 1087$ & $55.2 \pm 1.16$ & 5 \\
\hline MPL & 50 & 200 & 80 & 300 & 3 & 50 & $\mathrm{NL}$ & 400 & \\
\hline Significance & $*$ & $*$ & $*$ & $*$ & $*$ & $*$ & $*$ & $*$ & \\
\hline
\end{tabular}

Note: Significant at $\mathrm{P}=0.05$

MPL - Maximum Permissible Limit (USEPA Standards)

NS - Not Significant

NL - No limit

Table 2. Mean heavy metal concentrations ( $\mathrm{ppm} \pm \mathrm{SE}$ ) in maize plants (with cobs removed) from site A and from site B

\begin{tabular}{|c|c|c|c|c|c|c|c|c|}
\hline Treatment & $\mathrm{Cu}$ & $\mathrm{Zn}$ & $\mathrm{Mn}$ & $\mathrm{Pb}$ & $\mathrm{Cd}$ & $\mathrm{Ni}$ & $\mathrm{Fe}$ & $\mathrm{Cr}$ \\
\hline Site A & $4.8 \pm 0.06$ & $120 \pm 1.15$ & $28 \pm 0.58$ & $56 \pm 2.31$ & $1.4 \pm 0.06$ & $2.4 \pm 0.12$ & $\begin{array}{c}800 \pm \\
17.32\end{array}$ & $32 \pm 1.15$ \\
\hline Site B & $3.8 \pm 0.06$ & $24 \pm 1.73$ & $24 \pm 0.58$ & $10 \pm 1.15$ & $1.2 \pm 0.06$ & $2.2 \pm 0.06$ & $\begin{array}{c}700 \pm \\
11.55\end{array}$ & $36 \pm 2.31$ \\
\hline PML & 20 & 50 & 30 & 10 & 0.5 & 2 & 1000 & 50 \\
\hline Significance & $*$ & $*$ & $*$ & $*$ & $\mathrm{NS}$ & $\mathrm{NS}$ & $*$ & $\mathrm{NS}$ \\
\hline
\end{tabular}

Note: Significant at $\mathrm{P}=0.05$

NS - Not Significant

PML - Permissible Maximum Limits (WHO standards)

Table 3. Mean heavy metal concentrations $(\mathrm{ppm} \pm \mathrm{SE}$ ) in maize cobs from site $\mathrm{A}$ and from site $\mathrm{B}$

\begin{tabular}{|c|c|c|c|c|c|c|c|c|}
\hline Treatment & $\mathrm{Cu}$ & $\mathrm{Zn}$ & $\mathrm{Mn}$ & $\mathrm{Pb}$ & $\mathrm{Cd}$ & $\mathrm{Ni}$ & $\mathrm{Fe}$ & $\mathrm{Cr}$ \\
\hline Site A & $11 \pm 0.46$ & $70 \pm 0.58$ & $21.3 \pm 1.76$ & $52 \pm 2.3$ & $1.6 \pm 0.06$ & $3 \pm 0.12$ & $8605 \pm 0.8$ & $1221 \pm .2$ \\
\hline Site B & $6.6 \pm 0.2$ & $22.4 \pm 0.28$ & $20 \pm 0.58$ & $8.4 \pm 0.1$ & $1.0 \pm 0.12$ & $2.6 \pm 0.1$ & $760 \pm 5.8$ & $52 \pm 0.58$ \\
\hline PML & 20 & 50 & 30 & 10 & 0.5 & 2 & 1000 & 100 \\
\hline Significance & $*$ & $*$ & $*$ & $*$ & $*$ & $*$ & $*$ & $*$ \\
\hline
\end{tabular}

Note: Significant at $\mathrm{p}=0.05$

NS - Not Significant

PML - Permissible Maximum Limits (WHO standards) 
Table 4. Transfer factors for $\mathrm{Cu}, \mathrm{Zn}, \mathrm{Mn}, \mathrm{Pb}$ and $\mathrm{Fe}$ between the soil and the maize plant for site $\mathrm{A}$

\begin{tabular}{|c|c|c|c|c|c|}
\hline & $\mathrm{Cu}$ & $\mathrm{Zn}$ & $\mathrm{Mn}$ & $\mathrm{Pb}$ & $\mathrm{Fe}$ \\
\hline Soil $(\mathrm{ppm})$ & 94.4 & 285.4 & 77.5 & 94 & 31808 \\
\hline Maize plant $(\mathrm{ppm})$ & 4.8 & 120 & 28 & 56 & 800 \\
\hline Transfer factor & 0.05 & 0.42 & 0.36 & 0.59 & 0.025 \\
\hline
\end{tabular}

